\title{
新たな最適化手法を用いた工学システム設計ツールの提案*1 The Tool for Designing Engineering Systems Using a New Optimization Method Based on a Stochastic Process
}

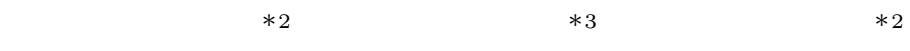 \\ Hiroaki YoshidA, Katsuhito Yamaguchi and Yoshio IshiKawA
}

Key Words : Optimum Design Methodology, Integrated Optimization, Stochastic Process, Airplane Configuration, Flight Trajectory

\begin{abstract}
The conventional optimization methods were based on a deterministic approach, since their purpose is to find out an exact solution. However, these methods have initial condition dependence and risk of falling into local solution. In this paper, we propose a new optimization method based on a concept of path integral method used in quantum mechanics. The method obtains a solutions as an expected value (stochastic average) using a stochastic process. The advantages of this method are not to be affected by initial conditions and not to need techniques based on experiences. We applied the new optimization method to a design of the hang glider. In this problem, not only the hang glider design but also its flight trajectory were optimized. The numerical calculation results showed that the method has a sufficient performance.
\end{abstract}

記 号の 説 明

\section{$A:$ 規格化定数}

$A^{\mathrm{m}}:$ 主翼アスペクト比

$A^{\mathrm{h}}:$ 水平尾翼アスペクト比

$A_{\mathrm{g} . \mathrm{e}}^{\mathrm{m}}$ : 地面効果を考慮した主翼のアスペクト比

$b^{\mathrm{m}}:$ 主翼翼幅

$b^{\mathrm{h}}:$ 水平尾翼翼幅

$c^{\mathrm{m}}:$ 主翼翼弦長

$c^{\mathrm{h}}:$ 水平尾翼翼弦長

$\overline{c^{\mathrm{m}}}:$ 主翼の空力平均弦長

$C_{\mathrm{D}}$ : 抗力係数

$C_{\mathrm{Df}}:$ フェアリングの抗力係数, 0.06

$C_{\mathrm{Di}}:$ 誘導抗力係数

$C_{\mathrm{D} 0}:$ 有害抗力係数

$C_{\mathrm{L}}:$ 揚力係数

$C_{\mathrm{D}}^{*}$ : 地面効果を考慮した抗力係数

$C_{\mathrm{D} 0}^{\mathrm{m}}:$ 主翼の最小有害抗力

$C_{\mathrm{D} 0}^{\mathrm{h}}:$ 水平尾翼の最小有害抗力

$D_{\mathrm{i}}:$ 誘導抗力

$D_{j}(j=1,2,3,4,5):$ 各翼桁および胴体パイプの径

$g:$ 重力加速度

$h:$ プランク定数，または摇らぎを与えるパラメター

$I:$ 評価関数

$K_{\max }:$ 計算打ち切り回数

*1 C) 2005 日本航空宇宙学会

平成 16 年 11 月 15 日原稿受理

*2 日本大学理工学部

*3 日本大学短期大学部
$L:$ 揚力

$L(x, \mathrm{~d} x / \mathrm{d} t, \mathrm{~d} t):$ ラグランジュ関数

$L_{\mathrm{t}}:$ 機体胴体パイプ長

$L^{\mathrm{h}}:$ 機体重心から水平尾翼パイプまでの距離

$m:$ 機体質量とパイロット質量の和

$m_{\mathrm{b}}:$ 機体質量

$m_{\mathrm{p}}:$ パイロット質量, $60 \mathrm{~kg}$

$P:$ 確率

$S:$ 作用積分

$S_{\mathrm{f}}$ : フェアリングの代表断面積, $0.25 \mathrm{~m}^{2}$

$S^{\mathrm{m}}:$ 主翼面積

$S^{\mathrm{h}}:$ 水平尾翼面積

$t:$ 時間

$T_{j}(j=1,2,3,4,5):$ 各翼桁および同体パイプの厚さ

$V:$ 速度

$V_{0}:$ 初速度

$V^{\mathrm{h}}:$ 水平尾翼容積比

$x:$ 水平方向距離

$x_{i}:$ 時刻 $t_{i}$ における位置

$x_{i}^{\mathrm{b}}: i$ 番目の機体の設計変数

$x_{i}^{\mathrm{u}}:$ 時刻 $t_{i}$ における飛翔体の操縦変数

$\left\langle x_{i}\right\rangle: x_{i}$ の期待値

$\boldsymbol{x}:$ 設計変数ベクトル

$x^{\mathrm{b}}:$ 飛翔体の機体設計変数

$\boldsymbol{x}^{\mathrm{u}}:$ 飛翔体の操縦変数

$z:$ 高度

$\alpha:$ 迎角

$\alpha_{0}$ : 主翼翼型のゼ口揚力迎角 , $-6.8 \mathrm{deg}$

$\alpha_{C_{\mathrm{L}}=2.0}$ : 揚力係数が 2.0 となる迎角 
新たな最適化手法を用いた工学システム設計ツールの提案 (吉田洋明・山口雄仁・石川芳男)

$\gamma:$ 経路角

$\lambda^{\mathrm{m}}:$ 主翼テーパ比

$\lambda^{\mathrm{h}}:$ 水平尾翼テーパ比

$\rho:$ 大気密度, $1.225 \mathrm{~kg} / \mathrm{m}^{3}$

$\sigma_{\mathrm{al}}:$ アルミニウム合金の $0.2 \%$ 引張圧縮耐力 , $3.04 \times$ $10^{8} \mathrm{~N} / \mathrm{m}^{2}$

$\sigma_{j}(j=1,2,3,4):$ 各パイプ付根に働く自重による曲 げ応力

$\sigma_{j}^{\text {aero }}(j=1,2,3,4)$ : 各パイプ付根に働く空気力による曲 げ応力

$\tau_{\mathrm{al}}:$ アルミニウム合金の $0.2 \%$ 剪断耐力, $2.75 \times$ $10^{8} \mathrm{~N} / \mathrm{m}^{2}$

$\tau_{j}:$ 各パイプ付根に働く自重による剪断応力 $\tau_{j}^{\text {aero }}(j=1,2,3,4)$ : 各パイプ付根に働く空気力による剪 断応力

\section{1. は じめに}

現実的なシステムの設計を行う場合には，何らかの形で 最適化が求められるのが一般的である.しかしながら , 現 実的なシステムでは, パラメターの数が多数にのぼり，か つ多くの拘束条件が付加されることがほとんどであるため， 解空間の形が複雑となり，厳密解を直接探索することはき わめて困難である .

また , システムを設計するためには, 最終的には厳密な 最適解が必要であるが, 設計の初期段階においてはシステ ムを構成する各要素の性能がシステムの全体性能に与える 影響を見積もる程度の近似解で十分な場合も多い.あるい は, 何らかの方法で最適解の近似解か赇められたなら, 光 の近似解を新たな初期值として従来の局所的最適化手法を 適用することにより，初期値依存性の問題や局所解に陥る 危険性を最小限に抑えながら，低い計算コストで厳密な最 適解を求めることが可能である.

すでに我々は，量子力学で使われている経路積分の概念 に基づき, 確率過程を用いて最適解の高近似解を求める手 法を提案している ${ }^{1 \sim 6)}$. 本稿では, この手法を具体的な工学 的最適化問題へ適用することができるように構成し，沉用 性の高い設計ツールとして提案する .

この設計ツールの構成と光の有効性を示すため, 具体的 な工学的最適化問題として既に Suzuki らによって他の方法 で解かれたハンググライダーの機体形状と構造および飛行 経路の統合的最適化問題7)を取り上げる.この問題は, 形 状と構造という静的変数の最適化問題と飛行経路という動 的変数の最適化問題の両方を含んでいるだけでなく，静的 变数である形状と構造の最適化部分も光れ単独では評価す ることができず, 動的変数である飛行経路の最適化部分ま で含めなければ光の全体性能を評価することができないと いう特徵を持っている．また，ここで提案するアルゴリズ ムは非常に単純な構造であるため, この問題への適用例を 示せば他の問題への適用は容易であると思われる .すなわ ち, 静的設計变数のみを含む最適化問題へ本ツールを適用 する場合には動的変数の最適化部分を取り除き，逆に動的
変数のみから成る問題へ適用する場合には静的変数の最適 化部分を取り除いて適用することができる．したがって本 稿では, このハンググライダーの統合的最適化問題に対す る本ツールの有効性を示すが , これは静的あるいは動的の みの設計变数からなる最適化問題への有効性も同時に示す ものである .

ところで最近になって，量子力学的概念を最適制御問題 に適用しようとする研究 ${ }^{8,9)}$ が見られるようになった .こ れらは，発想において我々と類似の認識を示すものである。 しかし，具体的な工学的問題に適用可能なツールは，まだ 提案されていない。

\section{2. 工学的最適化問題に対する近似解法}

数理計画法あるいはヒューリスティック法を問わず, 従 来の最適化手法は, 基本的には厳密解を求めることを目的 として，直接的あるいは確率的に解空間の「探索」を行っ ていた . 弚の結果, 効率よく解を探索するためには, 解く べき問題の性質に合わせて解の探索過程を経験的に制御す る必要があった . また, 解空間の局所的傾きなど, 解空間 の情報を利用して解を探索する方法では，得られる解が初 期值に依存することや得られた解が局所解である可能性が あるため，これらの危険を避けるためのさまざまな工夫を 必要としていた .さらに, 拘束条件か課せられた問題の場 合には, 解が拘束条件を満たすための工夫も必要であった . また，参考となる既存のシステムが存在しない全く新しい システムや多くの拘束条件か課せられているために解空間 が狭められているシステムの設計においては, 最適解の探 索を始めるための初期值を設定することすら困難であり， これを発見することに多くの時間を費やさなければならな かった .

以上のように, 従来の最適化手法では, 最適解を得るた めに多大な労力を必要としていた .これらの労力も, 厳密 解が必要なシステムの最終的な詳細設計の段階では十分に 見合うものであると考えられる．しかしながら設計の初期 段階では，近似解を手軽に得られた方が便利なことが多い． 例えば，ある新しいシステムの概念設計の過程で, 光の構 成装置の 1 つに複数の候補が存在したとき, 弚れ光れの装 置について最適化を行って, 弚れらがシステムの全体性能 へ与える影響を見積もることにより，これらの装置に優先 順位を付ける程度の情報を得たい場合などである．

本手法は，厳密解を探索する過程を含んでおらず，解を 探索するための試行錯誤的なパラメター調整に時間をかけ る必要がない，また，光も光も問題が確率過程に置き換え られていることから本質的に初期值依存性がないため，適 切な初期値を設定する手間や複数の初期値による解の比較 を行う必要もない，さらに，モンテカルロ法を利用した数 値計算に乗せやすいうえ，アルゴリズムが非常に簡潔であ る. 光して, 確率過程を用いて生成されるすべての解は互 いに独立であるため，並列計算の有効性を十分に生かした 数值計算を容易に行えるだけでなく，過去に得られた最適 解すなわち期待値と新たに得られた期待値とからさらに精 
度のよい最適解を求めることも可能である .

工学的な問題では, 一般に設計変数の変化に対する評価 関数の変化が比較的連続で骨らかであることが予想される ため，本手法によって十分に精度の高い近似解を得ること が期待できる.さらに ,一般性の高い簡潔なアルゴリズム によって構成されているため, 本手法は工学的な設計問題 に対して非常に有用性の高いものである.

\section{3. 確率過程を用いた最適化手法}

Simulated Annealing (SA) や Genetic Algorithms (GA) などのヒューリスティックな最適化手法では, 評価 関数の值に従って解を発生させ, クーリング・スケジュー ルや交差・突然変異などの演算により最も評価値の高い解 を探索する．我々は，これらの手法と同樣な確率過程に準 拠しながらも，全く新しい量に注目することにより，最適 解の近似解を効率よく得る方法を提案する．ここで我々が 注目する量は，「期待値」である．混同を恐れずあえて SA の計算過程にな光らえて説明するなら，演算過程で次々と 得られるさまざまな解を用いて計算された期待値（確率平 均) は最適解の近似解を与えるものと考えることができる なぜなら，与えられた確率分布に従ってさまざまに得られ た多くの解は，真の最適解をピークとして光の周辺に連続 的に分布しているものと期待されるからである.我々の手 法には，SA におけるアニーリング過程のような解の探索 過程はいっさい含まれていない, 兴の代わり, 評価関数值 がよい解ほど高い頻度でこれを発生させるメカニズムを用 いる. 弚して，こうして得られた多くの解と光の確率のす べてを用いて期待値を計算することで，最適解の近似解を 求める.

我々のこの発想は, 量子力学的運動と古典力学的運動の 関連から得られたものである.よく知られているように ,古 典力学では粒子の運動は，次式の作用積分

$$
S=\int_{t_{1}}^{t_{2}} L(x, \mathrm{~d} x / \mathrm{d} t, t) \mathrm{d} t
$$

に関する変分を最小とする運動であり，この運動経路はた だ $1 つ に$ 確定する.これに対し，量子力学的運動において は経路は 1 つに確定せず, 次式の確率

$$
P=\frac{1}{A} \exp (-S / h)
$$

に従ってさまざまな経路が発生し得る．このとき，Sが最 小となる経路 (古典的経路) は, 最も発生確率の高い経路で はあるが, 光の他の経路もある確率に従って発生する. 光 して, 量子論て理論的に予測可能であるのは, これらの経 路の期待值である.

Feynman らの経路積分法 ${ }^{10)}$ によれば，この期待值は，次 式の多重積分の形で表現することができる．すなわち

$$
\left\langle x_{i}\right\rangle=\int_{-\infty}^{\infty} \cdots \int_{-\infty}^{\infty}\left[P(\boldsymbol{x}) \cdot x_{i}\right] \mathrm{d} x_{1} \mathrm{~d} x_{2} \cdots \mathrm{d} x_{N}
$$

乥して, 確率分布が連続的であるなら, 上式で与えられる 期待值は古典力学的経路のよい近似解となることが期待で きる .

我々は, 式 (1)の作用積分 $S$ を形式的に評価関数 $I$ で置 き換え，一般的な工学的最適化手法として定式化を行う.

以下に SA の確率過程に準拠する場合について (後述す るように，必ずしもこれに準拠する必要はない)，我々の手 法の具体的な計算過程を説明する.

まず, 評価関数を $I$ として $\mathrm{SA}$ と同樣に確率分布 $P$ を次 式のように定義する .

$$
P=\frac{1}{A} \exp (-I / h)
$$

確率分布を式 (4)のように定義することにより, 評価関数 值が最も小さい最適解が確率のピークとなり, 光れ以外の 解は光の周辺に分布することになる .ここに,$h$ は解のゆ らぎを与える任意のパラメターである．すなわち， $h$ は $P$ の分布幅の大きさを定めるパラメターであり，hが大きい 場合は広く緩やかな分布を，また小さければ狭く急峻な分 布を与える.SA では，このhが温度パラメターであり，こ れを一定のルールに基づいて徐々に 0 へ近づけてゆくこと で唯一の最適解を探索するが，本手法では有限の固定值で あり，得られた多くの解はすべて保存される．また， $A$ は 確率の総和を 1 とするための規格化定数である .

つぎに, $L$ 個の静的設計変数を $x^{(1)}, x^{(2)}, \cdots, x^{(L)}$ と表 し, 設計変数ベクトルの成分とする .

さらに, $M$ 個の動的設計変数 $x^{(L+1)}, \cdots, x^{(L+M)}$ が 含まれている場合には，これを時間方向に $N$ 分割して $x_{0}^{(L+1)}, \cdots, x_{N}^{(L+1)}, x_{0}^{(L+2)}, \cdots, x_{N}^{(L+2)}, \cdots, x_{0}^{(L+M)}, \cdots$, $x_{N}^{(L+M)}$ とし時間履歴とする.これらをまとめて以下のよ うな設計変数ベクトルとして表すことができる .

$$
\begin{aligned}
\boldsymbol{x}= & \left\{x^{(1)}, x^{(2)}, \cdots, x^{(L)}, x_{0}^{(L+1)}, x_{1}^{(L+1)}, \cdots, x_{N}^{(L+1)},\right. \\
& \left.x_{0}^{(L+2)}, \cdots, x_{N}^{(L+2)}, \cdots, x_{0}^{(L+M)}, \cdots, x_{N}^{(L+M)}\right\} \\
= & x_{i} \quad(i=1 \sim L+M \times(N+1))
\end{aligned}
$$

最後に, 期待值の計算を行う . ある 1 つの設計変数べク トル $\boldsymbol{x}$ (1つの解) に対する評価関数が $I(\boldsymbol{x})$ であるとき， 弚の確率は式 $(4)$ より $P(\boldsymbol{x})$ であるから, 設計变数 $x_{i}$ の期 待値 $\left\langle x_{i}\right\rangle$ は次式のように求めることができる .

$$
\left\langle x_{i}\right\rangle=\int_{-\infty}^{\infty} \cdots \int_{-\infty}^{\infty}\left[P(\boldsymbol{x}) \cdot x_{i}\right] \mathrm{d} x_{1} \mathrm{~d} x_{2} \cdots \mathrm{d} x_{L+M \times(N+1)}
$$

ところで，SA は式 (4) で定義した確率分布 $P$ を利用し て解空間内の厳密解を「探索」する方法であり, 弚の際式 (4) の確率分布 $P$ に含まれる温度パラメター $h$ を徐々に小 さくすることで確率的な解の探索範囲を狭めていき，唯一 の最適解を発見しようとするものである．つまり，SA は 解を探索する指針として確率を利用した手法である。した がって SA では，解空間が多峰性である場合，この温度パ 
ラメター $h$ を変化させるスケジュールをうまく制御しない と解が収束しなかったり，局所解にとらわれたまま最適解 を発見できないなどの現象が生ずる.

しかし, 期待値に着目した本最適化手法では, 解の探索 は行われない . 最適解は式 (4)の $h$ の值を有限の值に固定 したまま，式 (6) の多重積分を行うことで求められる．す なわち, 考えられるすべての設計変数と谷の出現確率を掛 け合わせて，弚れらのすべてを足し合わせることで最適解 の近似解として期待值を計算する．したがって本手法では， $\mathrm{SA}$ や従来の最適化手法で行われているような，解くべき 問題の特性に合わせて解の探索過程をチューニングすると いった工夫を必要としない .

\section{4. 設計ツールの提案}

ここでは，提案する最適化手法を設計ツールとして利用 する方法を説明するための例題として，ハンググライダー の最大滑空距離問題を取り上げ, 光の機体形状と構造およ び飛行経路を統合的に最適化する.本問題は，機体形状と 構造 (合わせて機体設計变数と呼ぶ) という静的変数と飛 行経路という動的変数の両方を含んでいるだけでなく，こ れらを独立に扱うことはできないという特徵を持っている． すなわち, 静的変数である機体設計変数 (形状と構造) は 動的变数である操縦操作 (飛行経路) に先立って決定され ねばならないが, これの本当の評価は, 続いて多数生成さ れる操縦操作 (飛行経路) に沿って機体を飛行させてみな くては決定できないという関係にある．したがって，本問 題は設計可能なすべての機体設計変数の組み合わせと, 各 機体が飛行可能なすべての飛行経路とから成る非常に広く 複雑な解空間を持っており，従来の厳密解を求める手法で は最適解を得ることが非常に困難な問題である．

本章では，この例題への適用例を示すことで本最適化手 法の有効性を示すとともに, 弚の適用方法を詳しく説明す ることで本手法が非常に一般的な形式を持っており，取り 扱いの容易な設計ツールとして成立することを示す．

4.1 統合的最適化アルゴリズム 一般には, 航空機の機 体設計諸元やエンジン性能が与えられると, 光の機体の飛 行性能が決まり, 乥して光の機体を用いて達成すべきミッ ションか指定されれば，これに最適な飛行経路が決定され る.ここでは問題の設定を変えて，ある指定されたミッショ ンを達成することができるよう，機体形状と構造（機体設 計变数) の決定および飛行経路生成を統合的に最適化する 問題を定式化する.

そこで, $m$ 個の要素からなる航空機の機体設計変数を $\boldsymbol{x}^{\mathrm{b}}=\left\{x_{1}^{\mathrm{b}}, x_{2}^{\mathrm{b}}, \cdots, x_{m}^{\mathrm{b}}\right\}$, 迎角などの操縦操作に関する時間 関数を時間方向に $n$ 個に離散化した時間履歴 (操縦履歴) を操縦変数 $\boldsymbol{x}^{\mathrm{u}}=\left\{x_{1}^{\mathrm{u}}, x_{2}^{\mathrm{u}}, \cdots, x_{n}^{\mathrm{u}}\right\}$ とすれば, これらを合 わせて最適化すべき設計変数の集合を $\boldsymbol{x}=\left\{\boldsymbol{x}^{\mathrm{b}}, \boldsymbol{x}^{\mathrm{u}}\right\}$ と表 すことができる .

ここで，まずアルゴリズムの大まかな流れを説明する． 計算の目的は式 (6)の多重積分を実行することであり，こ れを数值的に行うために, 今回はモンテカルロ法の一種で
あるメトロポリス法 ${ }^{11)}$ を利用している .メトロポリス法は， ある変数 $\boldsymbol{x}$ を，光の変数値の評価值 $I(\boldsymbol{x})$ によって定まる 確率分布 (式 (4)) に従うように生成することができる.し たがって，メトロポリス法を利用して性能のよい機体ほど 高い頻度でこれを発生させれば，これらの解の確率平均值 を計算することで, 期待值すなわち最適解の近似解を求め ることができる .このとき, 式 (4)の規格化定数 $A$ は 1 と してよい．これは，実際に確率分布に従って解を生成した 場合には，自動的に確率の総和は 1 となるためである．

以下に示す期待値 (多重積分) を求めるための数値積分 にはメトロポリス法を用いた確率的な解の生成が採用され ているため，一見すると SA と同樣な解空間内の確率的解 探索が行われているように見える.しかしこの確率的な解 の生成は期待値を求める式 (6) の多重積分を実行するため に行っているのであり，厳密な最適解を探索するためのも のではない，つまり，メトロポリス法を利用している部分 は, 単に式 (4) によって決まる確率に従った解の生成を行 うものであり，他の方法で置き換えても構わない，例えば， この解の生成には GA を利用することも可能である．弚の 場合には，GA で生成した解を式 (4) で定義した確率分布 に従って採用し，期待値の計算に利用することになる．

本例題において，最適解の近似解である期待值を求める 式 (6) の多重積分を数值的に実行する手順は次の通りであ る (第 1 図参照).

まず, $m$ 個の機体設計变数 $\boldsymbol{x}^{\mathrm{b}}=\left\{x_{1}^{\mathrm{b}}, x_{2}^{\mathrm{b}}, \cdots, x_{m}^{\mathrm{b}}\right\}$ を $m$ 個の乱数によって生成し, 形状と構造の 1 組 (機体 1 ) を決定する . 次に, $n$ 分割された迎角の時間履歴 $\boldsymbol{x}^{\mathrm{u}}=$ $\left\{x_{1}^{\mathrm{u}}, x_{2}^{\mathrm{u}}, \cdots, x_{n}^{\mathrm{u}}\right\}$ を $n$ 個の乱数によって 1 組生成する . 続 いて，この迎角時間履歴 (操縦操作) に従って機体 1 を飛 行させ, 兴の飛行経路によって決まる飛行距離をもとにこ のときの評価関数值 $I$ を計算する. 光して, この評価関数 值を用いて，この解すなわち機体 1 と飛行経路 1 の組み合 わせについての発生確率 $P$ を計算する .

上には，機体 1 に対する 1 本の飛行経路についてのみ述 ベたが，実際には固定された機体 1 に対して， $K_{\text {max }}^{\mathrm{u}}$ 本の 迎角履歴を乱数によって次々に生成し, 弚れらのすへててに ついて機体 1 を飛行させ, 光のときの飛行距離（評価関数 值) と弚れによって決まる $K_{\max }^{\mathrm{u}}$ 個の発生確率 $P$ を定める。 弚して，これら $K_{\text {max }}^{\mathrm{u}}$ 個の確率を用いて迎角履歴の各時刻 ごと ( $n$ 分割点上) の期待値 (確率平均) を求めることで, 機体 1 に対する準最適操縦履歴と兰れに対応する準最適飛 行経路を決定する.さらに，この準最適飛行経路によって 決まる飛行距離をもとに機体 1 に対する評価関数值と光の 発生確率か確定される。

次に，新たな機体 2 を生成し，これに対して上記の計算 手順を繰り返すことで, 機体 2 に対する準最適操縦履歴と 準最適飛行経路，さらに評価関数值と光の発生確率を計算 する

さらに，機体 3〜機体 $K_{\max }$ を生成し，これらについて

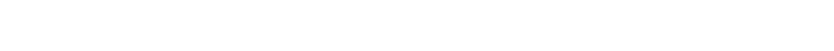
最適操縦履歴と準最適飛行経路さらに評価関数值と光の発 


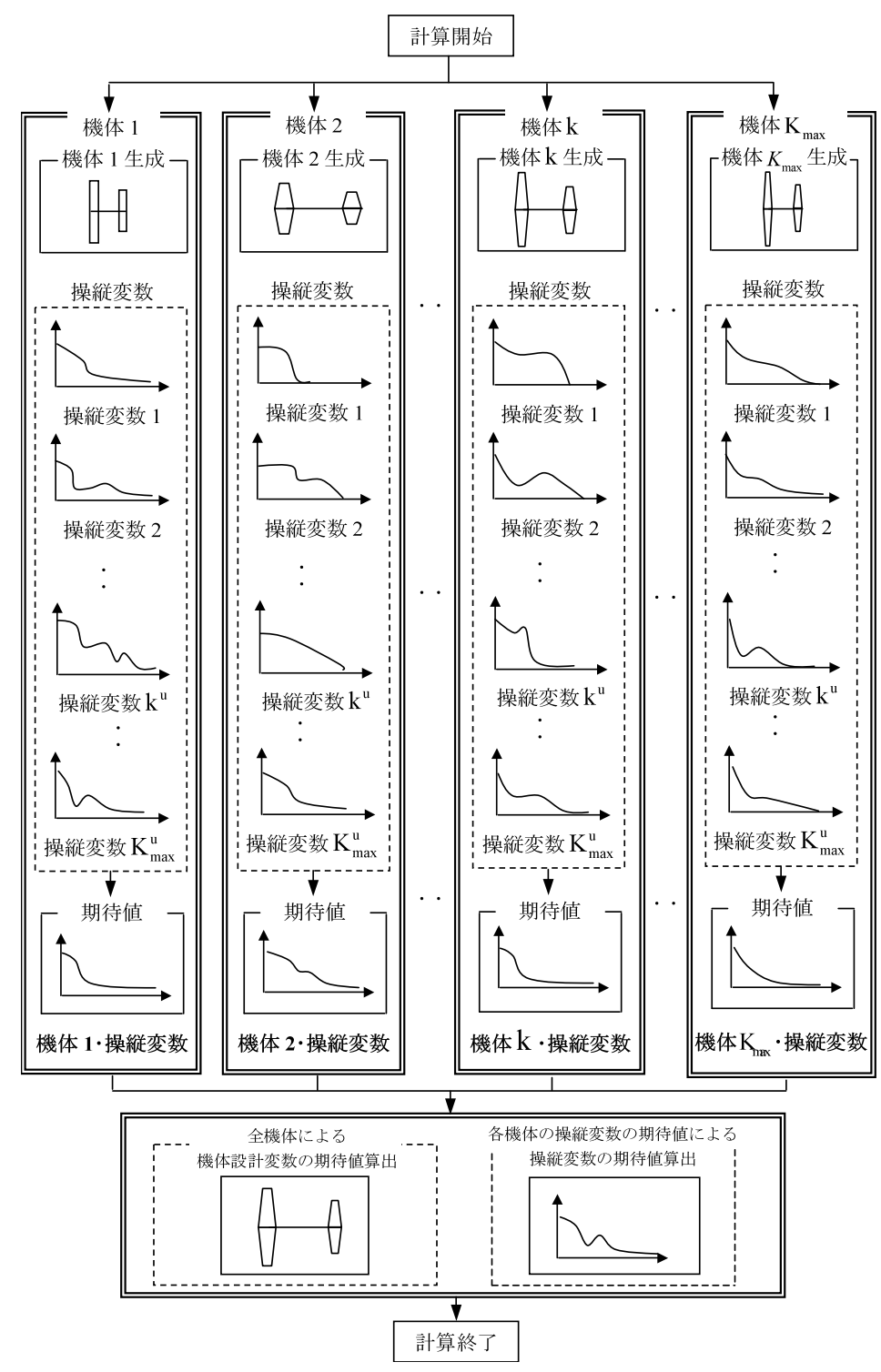

第 1 図 機体と飛行経路の統合的最適化計算のイメージ

生確率を計算する.

最後に , これらすべての機体についての $K_{\max }$ 個の発生 確率を用いて，すべての機体についての $K_{\max }$ 個の機体設 計変数および $K_{\max }$ 個の準最適操縦履歴の両者についての 期待值を計算することにより，1つの最適機体と光れに対 する最適操縦履歴が決定される. 弚して，この最適機体を この最適操縦履歴に従って飛行させることにより，最適飛 行経路 (最長飛行距離) が確定する.

実際の計算手順を以下に記す，光して，この計算手順の フローチャートを第 2 図に示す．いうなれば，図の左側の 流れは主プログラムであり機体設計フェーズを構成してい る. また，右側の光れはサブルーチン副プログラムに当た り，飛行経路生成フェーズを構成している.飛行経路の計 算のための副プログラムは, 主プログラムの 2 箇所で引用 されている.計算の終了条件は, 特別な工夫をせず, 単純 に計算打ち切り回数を指定することとし, 飛行経路最適化 の計算打ち切り回数を $K_{\text {max }}^{\mathrm{u}}$, 統合的最適化計算打ち切り
回数を $K_{\max }$ とする .もし十分な解が得られていないと判 断される場合には，さらに続けて計算を行えばよい．また， 第 2 図中に示されたステップ番号は, 以下の計算手順に付 けられたステップ番号に対応している .

Step 1. $m$ 個の成分からなる機体設計变数值 $x_{\mathrm{old}}^{\mathrm{b}}$ を $m$ 個 の乱数で生成し，これを初期機体とする.

Step 2. 機体設計変数值 $x_{\mathrm{old}}^{\mathrm{b}}$ に対して飛行経路の最適化を 行う.

Step 2-1. $n$ 個の成分 ( $n$ 分割) からなる離散操縦変数值 (時間履歴) $x_{\mathrm{old}}^{\mathrm{u}}$ を $n$ 個の乱数で生成し，二れを初期 飛行経路とする.

Step 2-2. この機体が操縦変数值 $x_{\mathrm{old}}^{\mathrm{u}}$ を採用したときの 評価関数値 $I_{\text {old }}^{\mathrm{u}}$ を計算する。

Step 1 で生成した機体 $x_{\text {old }}^{\mathrm{b}}$ Step 2-1 で生成した操 縱変数值 $x_{\mathrm{old}}^{\mathrm{u}}$ に従って滑空させ（機体の運動方程式を 数値的に解き), 弚の滑空距離に基づいて評価関数値を 求める. 


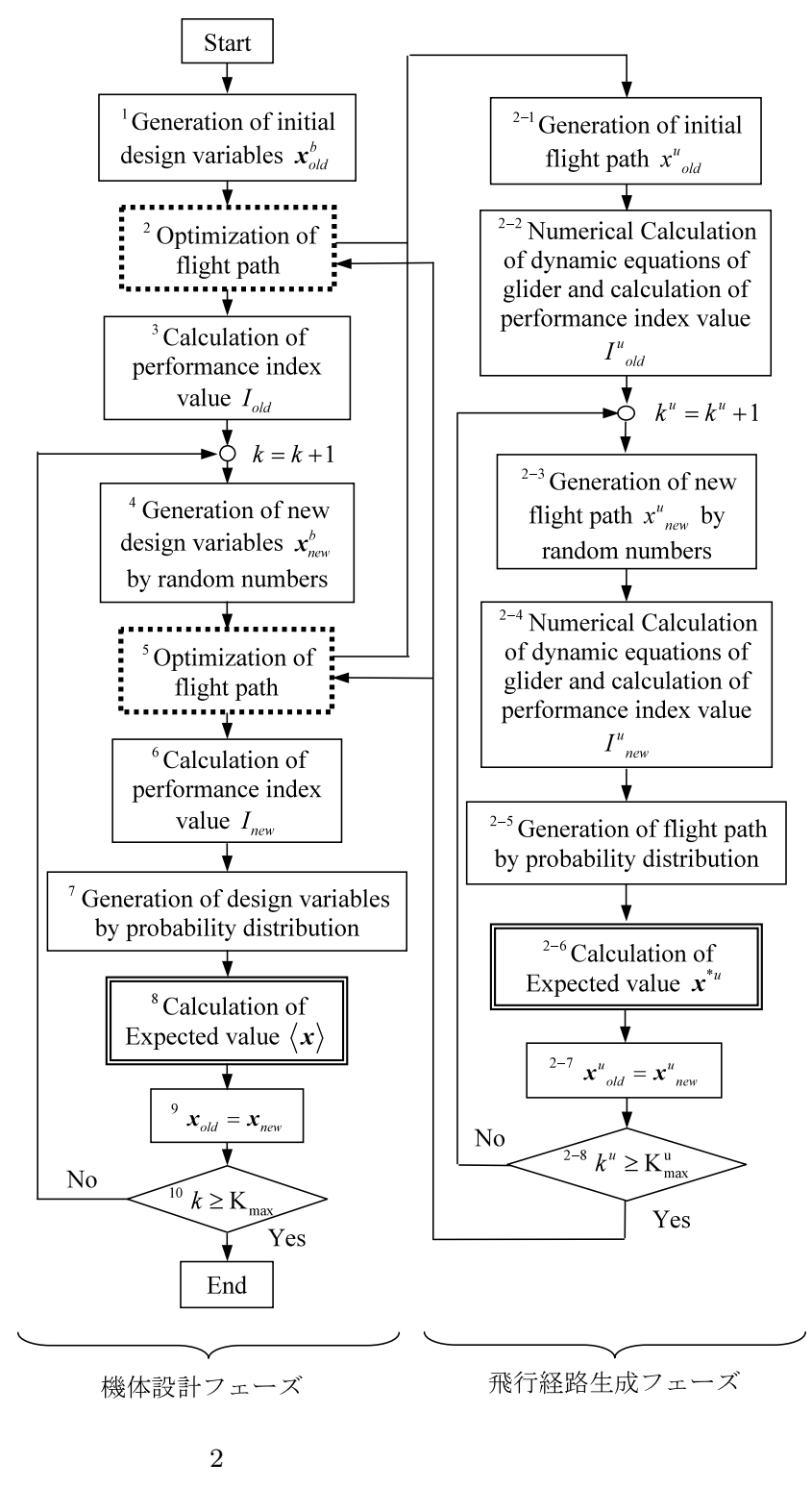

Step 2-3. 乱数により新たな操縱変数值 $x_{\mathrm{new}}^{\mathrm{u}}$ を生成する Step 2-4. 新たな操縱変数值 $x_{\text {new }}^{\mathrm{u}}$ に従って機体を滑空さ せ，これに対する評価関数值 $I_{\mathrm{new}}^{\mathrm{u}}$ を計算する。

Step 2-5. メトロポリス法を用いて, 評価関数値によって 定まる確率分布に従うように操縦変数值 $x_{\mathrm{old}}^{\mathrm{u}}$ か $x_{\mathrm{new}}^{\mathrm{u}}$ を選択する。

具体的には, $\Delta I^{\mathrm{u}}=I_{\mathrm{new}}^{\mathrm{u}}-I_{\mathrm{old}}^{\mathrm{u}}$ により $\Delta I^{\mathrm{u}} \leq 0$ (新 しい操縦変数值によって評価関数值か改善された場合) であれば $x_{\text {new }}^{\mathrm{u}}$ を採用するが, $\Delta I^{\mathrm{u}}>0$ (新しい操縦 変数值によって評価関数值が改悪された場合) であっ ても $\exp \left(-\Delta I^{\mathrm{u}} / h\right)$ の確率で $x_{\mathrm{new}}^{\mathrm{u}}$ を採用する. 光れ 以外の場合は $x_{\mathrm{old}}^{\mathrm{u}}$ を採用する，弚して，採用した操縦

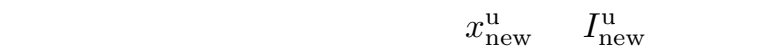
Step 2-6. 採用された操縦変数 $x_{\mathrm{new}}^{\mathrm{u}}$ を使って操縦変数の 期待值 $x^{* u}$ を計算する .

Step 2-7. 採用された操縦変数 $x_{\text {new }}^{\mathrm{u}}$ を $x_{\text {old }}^{\mathrm{u}}$ とする.

Step 2-8. $K_{\max }^{\mathrm{u}}$ 回この操作を繰り返し, 兴のつど操縦変 数の期待値 $x^{* \mathrm{u}}$ を更新する.
計算終了回数に達していれば計算を終了し，光うでな ければStep 2-3へ戻る .

Step 3. 機体設計変数 $x_{\mathrm{old}}^{\mathrm{b}}$ とこの機体に対して行った飛行 経路の最適化によって求めた操縦変数の期待値 $x^{* \mathrm{u}}$ を合 わせて $x_{\mathrm{old}}=\left\{x_{\mathrm{old}}^{\mathrm{b}}, x^{* \mathrm{u}}\right\}$ とし，この機体に対する評価 関数值 $I_{\mathrm{old}}$ を計算する。

Step 4. 乱数により新たな機体設計变数 $x_{\mathrm{new}}^{\mathrm{b}}$ を生成する. Step 5. 新たな機体設計変数 $x_{\mathrm{new}}^{\mathrm{b}}$ に対して Step 2 と同樣 に飛行経路の最適化を行う.

Step 6. 機体設計変数 $x_{\mathrm{new}}^{\mathrm{b}}$ とこの機体に対して行った飛行 経路の最適化によって求めた操緃変数の期待値 $x^{* \mathrm{u}}$ を合 わせて $x_{\mathrm{new}}=\left\{x_{\mathrm{new}}^{\mathrm{b}}, x^{* \mathrm{u}}\right\}$ とし，この機体に対する評価 関数值 $I_{\text {new }}$ を計算する.

Step 7. メトロポリス法を用いて評価関数值 $I_{\text {old }}$ と $I_{\text {new }}$ か ら定まる確率分布に従うように $x_{\text {old }}$ か $x_{\text {new }}$ を選択する 方法は Step 2-5 と同樣であり，採用された変数を $x_{\text {new }}$ とする

Step 8. 採用された変数 $x_{\text {new }}=\left\{x_{\text {new }}^{\mathrm{b}}, x^{* \mathrm{u}}\right\}$ を使って, 変 数の期待値 $\langle x\rangle$ を計算する.

Step 9. 採用された変数の組 $x_{\text {new }}$ を $x_{\text {old }}$ とする .

Step 10. $K_{\max }$ 回この操作を繰り返し, 弚のつと期待值 $\langle x\rangle$ を更新する .

計算終了回数に達していれば計算を終了し, 弚うでなけ ればStep 4 へ戻る . 計算が終了したとき , 期待值 $\langle x\rangle$ は 機体設計変数と操縱変数の最適解の近似解となっている. 以上のアルゴリズムが実現している計算のイメージは， 既に第 1 図として示された . 図中には，機体 1〜機体 $K_{\max }$ の各機体ごとに操縦履歴 1〜操縦履歴 $K_{\mathrm{max}}^{\mathrm{u}}$ の操緹履歴が 与えられている.実際の計算においては，各機体と各操縦 履歴の組み合わせすべてに対して , 運動方程式を数值的に 解くことによる飛行経路計算が行われる．また，この図で は, 複数の機体に対する飛行経路の期待值の計算を並列に 行い, 最後にすべての機体を使って最終的な期待值を求め る手順が示してあるので, 上に示したアルゴリズムと一致 していないように見える .これは上記のアルゴリズムが , 1 台の計算機 (CPU) で計算を行うことを前提としているた めである．しかし，上記のアルゴリズムに従って生成した機 体はおのおの独立であるため，このアルゴリズムに従って 計算された結果は，第 1 図に示すイメージのように，複数 の機体に対して並列に計算を行った結果と等価である。つ まり，上記のアルゴリズムは，第 1 図において並列に示し てある機体を左側から順番に 1 機ずつ操縦変数の期待值を 求め, 弚のつど機体に対する期待值の計算を行うよう示し たものである .

上記の計算手順とフローチャートは，一見すると SA の ものと非常によく似た形式を備えている.実際，計算手順 およびフローチャートから本手法の中心である式 (6) で表 される期待値の計算を行う Step 2-6 と Step 8 を取り除き， 本手法では固定值である摇らぎのパラメター $h$ を温度パラ メターとして何らかの方針に従って変化させたうえ, 最も 評価関数値のよい解を保存するようにすれば，SA による 
最適解の探索となる．しかしながら，本手法は最適解の近 似解を式 (6) の多重積分で表される期待值によって求めよ うとするものであるから，解の生成のためには必ずしもメ トロポリス法のようなモンテカルロ法を利用する必要はな い. 前述のように, 解の生成には GA を用いることも可能 であるから，GA のアルゴリズムを実現する計算手順を作 り，光こに式 (6) で表される期待值の計算を行う本計算手 順の Step 2-6やStep 8 を加えれば，ここに示したメトロ ポリス法を利用した場合と同樣に，本手法の計算手順を実 現できる .

また, 上記の計算手順は, 静的変数である機体設計変数 に関する部分と動的変数である飛行経路に関する部分とに 分けることができる．したがって，このアルゴリズムを静 的变数のみからなる最適化問題入適用する場合には, 動的 变数のみからなる最適化問題に関する部分, すなわち Step 2 と Step 5 を省略すればよく, 動的变数の最適化問題へ適 用する場合には，機体設計变数を定数として扱いStep 2 の みを適用すればよい .

つまり，上記の計算手順は工学的最適化問題一般に適用 することが可能な形式を備えている．

4.2 变数值の生成と拘束条件 前述のアルゴリズム中 には, Step 1, Step 2-1, Srep 2-3 , Step 2-5 , Step 4 お よびStep 5 に見られるように，変数值を生成する操作が存 在する.これらの変数值は乱数などによって生成されるが， 拘束条件によって変数値の採り得る範囲に制限がある場合 には，この制限内で変数值を生成すればよい．こうするこ とで, 拘束条件を事前に取り除いたことになり，有効な計 算のみを行うことができる .

4.3 状態量拘束条件 工学的最適化問題でしばしば現 れる状態量拘束条件は, 状態量に課せられる拘束条件であ るため，上に示した拘束条件のように事前に取り除くこと はできない.ここでは, 数値計算を行う上で取り扱いの容 易な 2 つの方法について示す．

（1）拘束条件を破る解を除外する方法

生成した解が拘束条件を満たしていない場合には，光の 解を単純に棄却する方法である.

この方法は, 拘束を破った解を期待値の算出，すなわち 最適解の近似解を求める計算には使わないため, 無駄な計 算か増えるが最も簡便な方法である。

(2) ペナルティ法

拘束を破った解も評価関数值を悪化させるための相応の 重みを付けて計算に利用する方法である .

本手法では, 式 (4)で明らかなように, 評価関数值の悪 い解は乥の評価関数值に従って指数関数的に発生確率が小 さくなり，期待値すなわち解への影響は小さくなる．この 性質を利用すれば，拘束条件を破った解の評価関数値には 拘束条件からの逸脱量に応じたペナルティ值を产の評価関 数値に加えることで, 弚うした解の発生確率产のものを小 さくすることができる．また通常，最適解は拘束条件に張 り付くことが多いため，わずかに拘束を破る解は最適解を 求める上で有効な情報を含んでいる。したがって，このぺ
ナルティ法は，拘束を破る解を単純に棄却する方法よりも， 生成した解を有効に利用することができる .

\section{5. ハンググライダーの機体形状と構造および} 飛行経路の統合的最適化問題

ここで, 具体的な航空機の機体形状と構造および飛行経 路の統合的最適化問題として, 第 1 表に示す 12 個の機体設 計変数と 1 つの操縱変数から成る第 3 図のようなハンググ ライダーを考える.すなわち，質量 $m_{\mathrm{p}}=60 \mathrm{~kg}$ のパイロッ 卜が背負い，第 4 图のように高度 $12 \mathrm{~m}$ から高度 $2 \mathrm{~m}$ まで 滑空したとき, 光の飛行距離が最大となる機体形状 (平面 形）と操縦変数すなわち迎角 $\alpha$ の時間履歴を求める問題に 本手法を適用する．弚の際，空気力によって翼が破損しな いよう構造についても最適化を行う．ただし，この問題は Suzuki らの方法によって過去に解かれた最適化問題〕に準 じている

5.1 機体の構成 ハンググライダーの運動を垂直平面内 に限定すると，機体は垂直尾翼を有さず, 主翼, 水平尾翼, 主翼翼桁パイプ, 水平尾翼翼桁パイプ, 胴体パイプ, フェ アリングから構成される、ただし，リブや翼面外皮等は考 慮しない．したがって，機体質量 $m_{\mathrm{b}}$ はパイプとフェアリ ングの質量の総和となる . また , 各パイプの素材はアルミ ニウム合金とし，主翼翼妳の先端から胴体付け根に向かっ て，第 1 パイプ, 第 2 パイプ, 第 3 パイプと呼び, 尾翼翼 桁を第 4 パイプ, 胴体パイプを第 5 パイプと呼ぶことにす る. 光して , 各主翼翼桁のパイプの径 $D_{j}(j=1,2,3)$ は設

\begin{tabular}{|c|c|c|}
\hline 変数名 & 単位 & 変数 \\
\hline \multicolumn{3}{|l|}{ 機体設計変数 } \\
\hline 主翼面積 & $\mathrm{m}^{2}$ & $S^{\mathrm{m}}$ \\
\hline 主翼縦横比 & — & $A^{\mathrm{m}}$ \\
\hline 主翼テーパ比 & - & $\lambda^{\mathrm{m}}$ \\
\hline 水平尾翼面積 & $\mathrm{m}^{2}$ & $S^{\mathrm{h}}$ \\
\hline 水平尾翼縦横比 & - & $A^{\mathrm{h}}$ \\
\hline 水平尾翼テーパ比 & - & $\lambda^{\mathrm{h}}$ \\
\hline 第 1 パイプ径 & $\mathrm{m}$ & $D_{1}$ \\
\hline 第 2 パイプ径 & $\mathrm{m}$ & $D_{2}$ \\
\hline 第 3 パイプ径 & $\mathrm{m}$ & $D_{3}$ \\
\hline 第 1 パイプ長 & $\mathrm{m}$ & $Y_{1}$ \\
\hline 第 2 パイプ長 & $\mathrm{m}$ & $Y_{2}$ \\
\hline 胴体パイプ長 & $\mathrm{m}$ & $L_{\mathrm{t}}$ \\
\hline \multicolumn{3}{|l|}{ 操縦変数 } \\
\hline 迎角 & $\operatorname{deg}$ & $\alpha$ \\
\hline
\end{tabular}

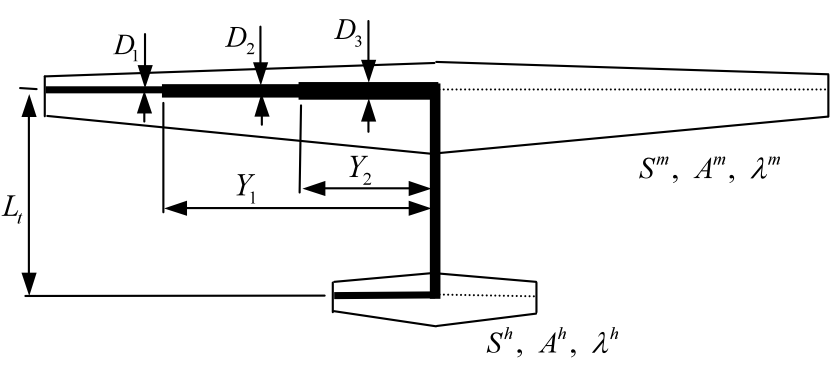

第 3 図＼cjkstart機体平面形状と構造および機体設計変数 


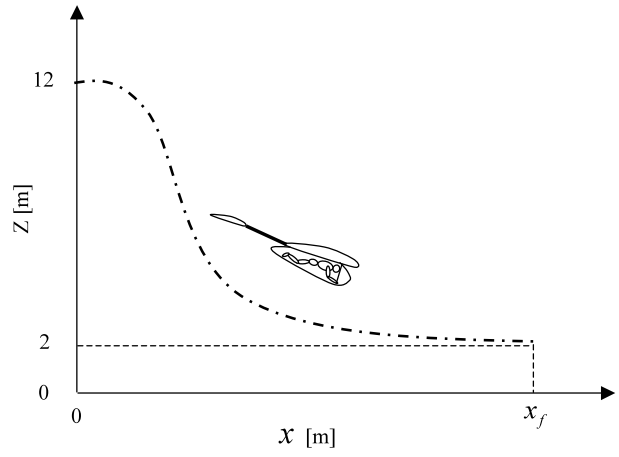

第 4 図 ハンググライダーの滑空問題

計変数として決まり，光の厚さ $T_{j}(j=1,2,3)$ は次式のよ うに各パイプ径の $2 \%$ とする .

$$
T_{j}=0.02 D_{j}
$$

また，尾翼翼桁パイプの径 $D_{4}$ と厚さ $T_{4}$ は $\left(D_{4}, T_{4}\right)=$ $\left(20 \times 10^{-3} \mathrm{~m}, 0.8 \times 10^{-3} \mathrm{~m}\right)$ とし，胴体パイプの径 $D_{5}$ と 厚さ $T_{5}$ は $\left(D_{5}, T_{5}\right)=\left(60 \times 10^{-3} \mathrm{~m}, 1.2 \times 10^{-3} \mathrm{~m}\right)$ と与 える。

翼の平面形状はテーパ翼とし，主翼翼型には EPPLER560 ${ }^{12)}$ を, 水平尾翼翼型には NACA0012 ${ }^{12)}$ を用い る.光して，これらの翼は胴体パイプに直角に取り付けら れ, 翼桁と翼型の空力中心 ( $1 / 4$ 弦長) は一致しているも のとする .

ところで, 機体には以下の拘束条件が課せられる．

1) 機体の設計変数として算出される水平尾翼翼幅 $b^{\mathrm{h}}$ は $3 \mathrm{~m}$ 以下であること :

$$
b^{\mathrm{h}} \leq 3 \mathrm{~m}
$$

2) 機体質量 $m_{\mathrm{b}}$ は $35 \mathrm{~kg}$ 以下であること :

$$
m_{\mathrm{b}} \leq 35 \mathrm{~kg}
$$

3) 縦の静安定性を考慮して, 次式で示される水平尾翼容 積比 $V^{\mathrm{h}}$ が 0.3 から 1.0 以内であること :

$$
\begin{aligned}
& 0.3 \leq V^{\mathrm{h}} \leq 1.0 \\
& V^{\mathrm{h}}=\frac{S^{\mathrm{h}} \cdot L^{\mathrm{h}}}{S^{\mathrm{m}} \cdot \overline{c^{\mathrm{m}}}}
\end{aligned}
$$

ただし， $L^{\mathrm{h}}$ は機体重心から水平尾翼パイプまでの距離であ る.主翼の空力中心翼弦長 $\bar{c}$ 严 はテーパ翼であるため次式 に従って算出される.

$$
\overline{c^{\mathrm{m}}}=\frac{4}{3} \cdot \frac{S^{\mathrm{m}}}{\left(1+\lambda^{\mathrm{m}}\right) \sqrt{S^{\mathrm{m}} A^{\mathrm{m}}}}\left(1+\frac{\left(\lambda^{\mathrm{m}}\right)^{2}}{1+\lambda^{\mathrm{m}}}\right)
$$

4) 地上待機中に翼桁が自重で破損しないよう，各パイ プ付け根に働く剪断応力 $\tau_{j}(j=1,2,3,4)$ と曲げ応力 $\sigma_{j}(j=1,2,3,4)$ は乥れ光れ材料の $0.2 \%$ 耐力 $\left(\tau_{\mathrm{al}}, \sigma_{\mathrm{al}}\right)$ 以 下となること :

$$
\tau_{j} \leq \tau_{\mathrm{al}}, \quad \sigma_{j} \leq \sigma_{\mathrm{al}}
$$

5) 翼型内に翼桁パイプが収まること

6) 主翼と水平尾翼が重ならないこと
5.2 空気力学 翼は 3 次元翼として取り扱う.また，一 般的にハンググライダーの翼はアスペクト比が大きいため， 翼弦方向の空力荷重分布を無視して, 揚力線理論を用いる。 これにより，翼の微小区間に働く揚力 $\mathrm{d} L$ と誘導抗力 $\mathrm{d} D_{\mathrm{i}}$ を求め, さらに揚力係数 $C_{\mathrm{L}}$ と抗力係数 $C_{\mathrm{D}}$ を求める.た だし， $C_{\mathrm{D}}$ は式 (14) に示すように, 誘導抗力係数 $C_{\mathrm{Di}}$ と有 害抗力係数 $C_{\mathrm{D} 0}$ との和であり， $C_{\mathrm{D} 0}$ は翼型データより得ら れる主翼と水平尾翼の最小有害抗力係数 $C_{\mathrm{D} 0}^{\mathrm{m}}, C_{\mathrm{D} 0}^{\mathrm{h}}$ および フェアリングの抗力係数 $C_{\mathrm{Df}}$ より式 (15) のように求まる.

$$
\begin{aligned}
& C_{\mathrm{D}}=C_{\mathrm{D} 0}+C_{\mathrm{Di}} \\
& C_{\mathrm{D} 0}=C_{\mathrm{D} 0}^{\mathrm{m}}+C_{\mathrm{D} 0}^{\mathrm{h}} \frac{S^{\mathrm{h}}}{S^{\mathrm{m}}}+C_{\mathrm{Df}} \frac{S_{\mathrm{f}}}{S^{\mathrm{m}}}
\end{aligned}
$$

一般的には, 翼には空力荷重による剪断, 曲げ, 捩り応 力が作用する、ただし，ここでは揚力線理論を用いている ため, 翼幅方向の $1 / 4$ 弦長線上にのみ空力荷重が働くと仮 定すれば, 翼桁パイプに働く応力は剪断と曲げのみとなる．

運動中に, 主翼と水平尾翼の翼桁が空力荷重によって破 損してはならない，乥こで，時々刻々変化する空力荷重に より各翼桁パイプに生じる剪断応力 $\tau_{j}^{\text {aero }}(j=1,2,3,4)$ お よび曲げ応力 $\sigma_{j}^{\text {aero }}(j=1,2,3,4)$ と，これらの $0.2 \%$ 耐力 との比が 1.5 以上でなければならないことを示す拘束を課 す.すなわち，

$$
\frac{\tau_{\mathrm{al}}}{\tau_{j}^{\text {aero }}} \geq 1.5, \quad \frac{\sigma_{\mathrm{al}}}{\sigma_{j}^{\text {aero }}} \geq 1.5
$$

ただし, 主翼翼椼に働く剪断応力 $\tau_{j}^{\text {aero }}(j=1,2,3)$ と曲げ 応力 $\sigma_{j}^{\text {aero }}(j=1,2,3)$ は, 先述の揚力線理論より求めた微 小区間に働く揚力 $\mathrm{d} L$ と, 主翼翼型の有害抗力 $C_{\mathrm{D} 0}^{\mathrm{m}}$ から求 められる有害抗力 $\mathrm{d} D_{0}^{\mathrm{m}}$ と誘導抗力 $\mathrm{d} D_{\mathrm{i}}$ との和である抗力 $\mathrm{d} D$ と各翼析パイプの重量より求めることができる.また， 水平尾翼翼桁に働く剪断応力 $\tau_{4}^{\text {aero }}$ と曲げ応力 $\sigma_{4}^{\text {aero }}$ につ いても同樣である.

5.3 運動 ハンググライダーを質点とみなせば，弚の 運動は操縦変数である迎角 $\alpha(t)$ によって決まる空力係数 を用いて，運動方程式を解くことにより求められる．ただ し， $\alpha(t)$ の取りうる範囲は, 次式のように主翼翼型のゼ口 揚力迎角 $\alpha_{0}(=-6.8 \mathrm{deg})$ から揚力係数が 2.0 となる迎角 $\alpha_{C_{\mathrm{L}}=2.0}$ とした .すなわち

$$
\alpha_{0} \leq \alpha \leq \alpha_{C_{\mathrm{L}}=2.0}
$$

実際の数值計算においては, 迎角を適当な時間間隔て離散 化し，各時刻における迎角を線形補間することで運動方程 式を解いている。

運動方程式を以下に示す．ここに， $m$ は機体とパイロッ トの質量の合計である .

$$
\begin{aligned}
& \dot{V}=-(1 / 2 m) \rho V^{2} C_{\mathrm{D}}^{*} S^{\mathrm{m}}-g \sin \gamma \\
& \dot{\gamma}=(1 / 2 m) \rho V C_{\mathrm{L}} S^{\mathrm{m}}-(g / V) \cos \gamma \\
& \dot{x}=V \cos \gamma \\
& \dot{z}=V \sin \gamma
\end{aligned}
$$




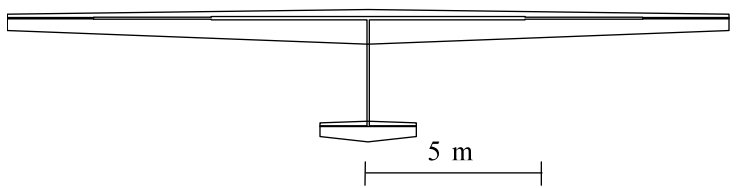

第 5 図 本手法により得られた機体の平面形

ただし， $C_{\mathrm{D}}^{*}$ は地面効果を考慮した式 $(22)$ で表される抗力 係数である.また，式 (22) 中の $A_{\mathrm{g}, \mathrm{e}}^{\mathrm{m}}$ は式 (23) で与えられ るように, 高度 $z$ と主翼翼幅 $b^{\mathrm{m}}$ で表される地面効果を考 慮したアスペクト比である。

$$
\begin{aligned}
& C_{\mathrm{D}}^{*}=C_{\mathrm{D} 0}+C_{\mathrm{Di}}\left(A^{\mathrm{m}} / A_{\mathrm{g} . \mathrm{e}}^{\mathrm{m}}\right) \\
& A_{\mathrm{g} . \mathrm{e}}^{\mathrm{m}}=\frac{33\left(z / b^{\mathrm{m}}\right)^{1.5}+1}{33\left(z / b^{\mathrm{m}}\right)^{1.5}}
\end{aligned}
$$

また，初期条件と終端条件は以下のようである．

- 初期条件 : 速度 $V_{0}=\sqrt{2000 / m} \mathrm{~m} / \mathrm{s}$, 高度 $z_{0}=12 \mathrm{~m}$, 経路角 $\gamma_{0}=-3.5 \mathrm{deg}$

·終端条件 : 高度 $z_{\mathrm{f}}=2 \mathrm{~m}$

5.4 評価関数と拘束条件の取り扱い 今回の機体に関 する拘束条件は，二れを満たさない解を棄却する方法で取 り扱う．したがって，機体を乱数によって生成する際には， 兴の拘束条件を満たすまて解を生成し続ける．また，状態 量に関する拘束条件にはペナルティ法を用い，拘束を破っ た場合には本来の評価関数値にペナルティ值を足し合わせ るものとする.したがって，ここで用いる評価関数は, 式 (24) および (25) のように, 飛行距離 $x_{\mathrm{f}}$ の絶対值の逆数 にペナルティ関数として各翼桁パイプに働く光れぞれの応 力の拘束超過量を規格化して足し合わせたものとした . 評 価関数を飛行距離の逆数としているのは, 問題を最小值問 題として取り扱うためである.

$$
\begin{aligned}
I=1 /\left|x_{\mathrm{f}}\right| & + \text { penalty } \\
\text { penalty }= & \sum_{\tau_{\mathrm{al}} / \tau_{j}^{\text {aero }}<1.5}\left(\tau_{j}^{\text {aero }} / \tau_{\mathrm{al}}\right) \\
& +\sum_{\sigma_{\mathrm{al}} / \sigma_{j}^{\text {aero }}<1.5}\left(\sigma_{j}^{\text {aero }} / \sigma_{\mathrm{al}}\right)
\end{aligned}
$$

\section{6. 適用結果および考察}

計算の終了条件として, 飛行経路最適化計算打ち切り回 数 $K_{\max }^{\mathrm{u}}=5000$, 統合的最適化計算打ち切り回数 $K_{\max }=$ 15000 を指定して計算を行った．すなわち，15000 機の機 体と光れらの各機体に対して 5000 本の操縦履歴 (飛行経 路）を用意した今回の計算に要した計算時間は Pentium 4 $(2 \mathrm{GHz})$ で 10 日程度であった . 本アルゴリズムによって 得られた機体を，第 5 図に示す．また，この機体の機体設 計変数值と機体質量および飛行距離を第 2 表に示す. 光し て, 飛行距離に対する迎角変化を第 6 図 (a)に，また飛行 距離に対する速度変化を第 6 図 (b)に,さらに飛行距離に 対する高度変化を第 6 図 (c) に示す. 第 6 図 (d) には, 各

\begin{tabular}{ccc} 
第 2 表 & \multicolumn{2}{l}{ 各変数の計算結果 } \\
\hline 変数 & 単位 & \\
\hline$S^{\mathrm{m}}$ & $\mathrm{m}^{2}$ & 16.2 \\
$A^{\mathrm{m}}$ & - & 25.4 \\
$\lambda^{\mathrm{m}}$ & - & 0.470 \\
$S^{\mathrm{h}}$ & $\mathrm{m}^{2}$ & 1.47 \\
$A^{\mathrm{h}}$ & - & 4.97 \\
$\lambda^{\mathrm{h}}$ & - & 0.659 \\
$D_{1}$ & $\mathrm{~m}$ & 0.0413 \\
$D_{2}$ & $\mathrm{~m}$ & 0.0716 \\
$D_{3}$ & $\mathrm{~m}$ & 0.0971 \\
$Y_{1}$ & $\mathrm{~m}$ & 7.73 \\
$Y_{2}$ & $\mathrm{~m}$ & 4.41 \\
$L_{\mathrm{t}}$ & $\mathrm{m}$ & 3.39 \\
$m_{\mathrm{t}}$ & $\mathrm{kg}$ & 20.3 \\
$x_{\mathrm{f}}$ & $\mathrm{m}$ & 357.6 \\
\hline
\end{tabular}

パイプ付け根に衝く曲げ応力比 $\sigma_{\mathrm{al}} / \sigma_{i}^{\text {aero }}(i=1,2,3,4)$ の 変化を示す。

今回提案したアルゴリズムに基づく設計ツールを用いて 得られたハンググライダーの機体と飛行経路は，過去に異 なる方法によって行われた最適化計算の結果7) とよく一致 しており，第 1 次近似解としては十分な精度の解が求めら れていることが分かる.

本稿で取り扱ったようなグライダーでは，高い滑空性能 を持たせるために誘導抗力の小さい高アスペクト比の主翼 を採用することが一般的であるが，今回の計算で得られた 機体は，第 5 図より分かるように，二れを実現している。

機体設計変数に対する拘束条件は，これを満たすように 解を生成しているためすべて満たされている．また，状態 量に対する拘束条件，すなわち飛行中に翼の各パイプ付け 根に働く曲げ応力と剪断応力についての拘束条件 (式 (16)) に対しては, ペナルティ法を用いて拘束を破る解も許容し ているが , 第 6 図 (d) に示す曲げ応力の時間履歴から分か るようにすべて拘束条件を満たしている．剪断応力に対す る時間履歴は示していないが, 同樣に拘束を満たしている. すなわち，構造に関する状態量拘束条件を合理的に満たす ためには，飛行状態つまり操縦操作の時間履歴を適切に設 定することが不可欠であるが，ここに得られた結果によれ ば，機体強度に関する拘束条件が操縦操作に反映されてい ることが分かる．

本問題は, 12 個の静的な機体設計变数と迎角の時間履歴 という 1 つの動的な設計変数を持ち，かつこれらが相互に 干渉し合う複雑な問題である.しかし, 以上の結果から， ここで提案した非常に単純で凩用性の高いアルゴリズムに よって，これらの統合的最適化が行われていることが分か る.また，本問題に対して解を得るまでに 10 日程度の計 算時間を要しており，他の手法に比へ計算時間を必要とす る手法のように思えるが , パラメターチューニングのため の試行錯誤的な計算を必要としないため, 定式化を行って から解を得るまでのトータルの時間では他の手法より短い 可能性がある. また，乱数による機体設計变数と操縦履歴 の生成は, 単純確率過程 (マルコフ過程) であるため, 文 字通りの単純な並列計算によって計算時間を短縮すること 


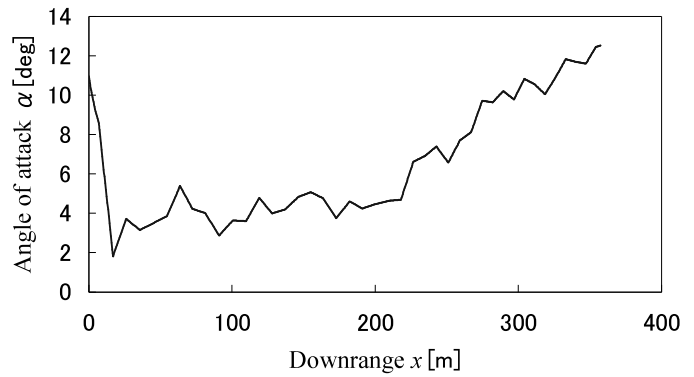

(a) Angle of attack vs. downrange

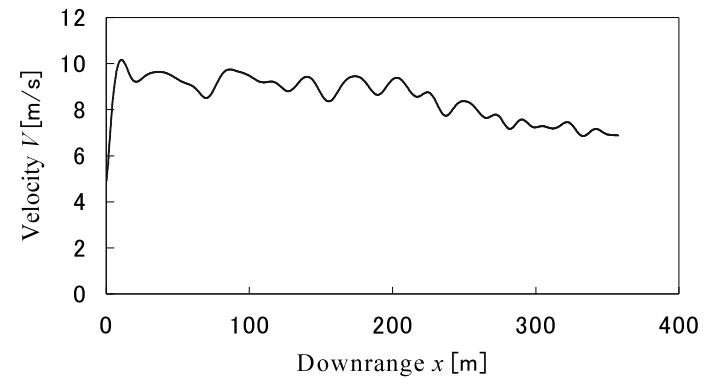

(b) Velocity vs. downrange

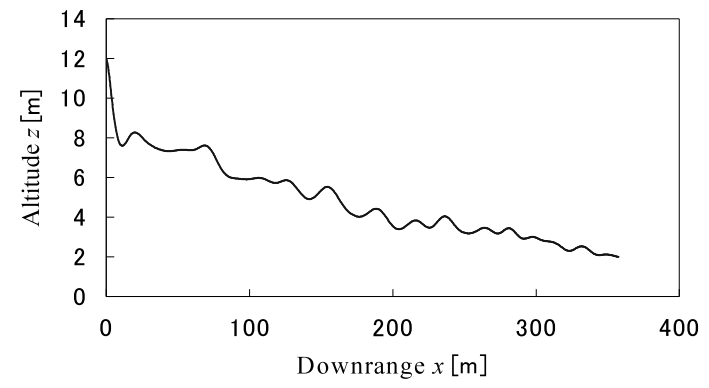

(c) Altitude vs. downrange

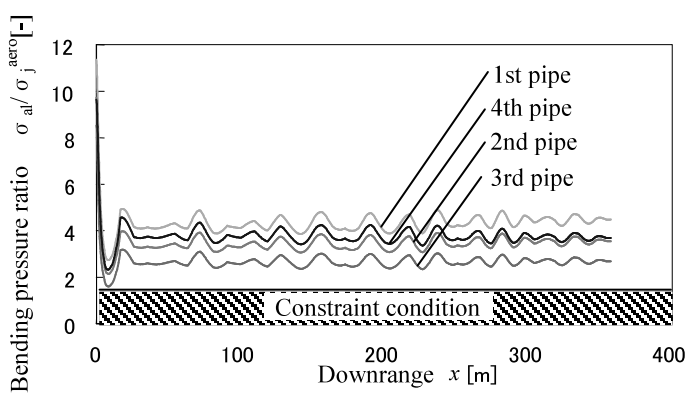

(d) Bending pressure ratio vs. downrange

\section{第 6 図 計算結果}

が, 本手法においては可能である .

$$
\text { 7. おわりに }
$$

確率過程を用いた新たな最適化手法を一般的な最適設計 ツールとして提案し，产の飛行距離が最大となるよう，八 ンググライダーの機体形状と構造および飛行経路を求める 統合的最適化問題にこれを適用した .この問題は，最適
な機体形状と構造という静的な設計変数を決定するために は，光の機体の飛行距離の最大化という動的な最適化問題 を解かなければ，弚の全体を評価することができないとい う特徵を持っている.すなわち, 静的変数と動的変数が互 いに独立ではないため，光れぞれを別々に最適化して加え 合わせても，光の全体性能を最大化することは不可能であ り，これこ光が一般的な工学的最適化問題の特徵である.

さらに, 本論文で最適設計ツールとして提案した数值計 算アルゴリズムには，適用する問題の特徵に合わせた工夫 をいっさい含んでいないため, 最適化問題一般に適用する ことが可能である .

以上より，ここに提案した新たな最適化手法と数值計算 アルゴリズムは, 静的あるいは動的さらに両者からなる複 合的工学的最適化問題一般に適用可能な設計ツールとして 有効であると考えられる .

\section{考 文 献}

1) Terasaki, M., Kondo, M., Yoshida, H., Yamaguchi, K. and Ishikawa, Y.: Integrated Optimization of Airplane Design and Flight Trajectory by New Optimization Method Using a Stochastic Process, Computational Mechanics WCCM VI in conjunction with APCOM'04, Tsinghua University Press \& Springer-Verlag, Beijing, 2004, Minisymposia Sessions \#MS053, paper \#328, pp. 1-9.

2) 近藤理良, 石川芳男, 山口雄仁, 吉田洋明 : 確率過程を用いた工 学的問題の近似解法, 第 6 回計算工学講演会論文集, 2001, pp. 139-140.

3) 吉田洋明, 近藤理良, 見城 武, 山口雄仁, 石川芳男 : 工学問題 における確率過程を用いた最適化手法 , 第 14 回計算力学講演会 講演論文集 , 2001, pp. 315-316.

4) 吉田洋明, 石川芳男, 山口雄仁, 近藤理良 : 経路積分の概念に基 づいた工学的最適化問題における新たな最適化手法 , 第 5 回最適 化シンポジウム講演論文集 , 2002, pp. 189-194.

5) 近藤理良, 吉田洋明, 山口雄仁, 石川芳男 : 確率過程を用いた最 適化問題の近似解法，第 15 回計算力学講演会講演論文集，2002, pp. 463-464.

6) 吉田洋明, 近藤理良, 山口雄仁, 石川芳男 : 確率過程を用いた新 たな最適化手法によるハンググライダーの機体設計と飛行経路の 統合的最適化 , 第 13 回設計工学・システム部門講演会講演論文 集 , 2003, pp. 102-105.

7) Suzuki, S. and Kawamura, N.: Simultaneous Optimization of Sailplane Design and Its Flight Trajectory, J. Aircraft, 33 (1996), pp. 567-571.

8) 伊丹哲朗 : 経路積分のモンテ・カルロ計算に基づく非線形最適制 御，システム制御情報学会論文誌， 16 (2003), pp. 637-648.

9) Itami, T.: An Open-Loop Calculation in a Path Integral Representation of Affine Nonlinear Optimal Control Systems with Control Costs Quadratic in Control Variables, Trans. of the Society of Instrument and Control Engineers, 40 (2004), pp. $18-27$.

10) Feynman, R. P. and Hibbs, A. R.: Quantum Mechanics and Path Integrals, McGraw-Hill Inc., 1965.

11) 神山真一，佐藤 明：モンテカルロ・シミュレーション，朝倉書 店，東京，1997, pp. 28-66.

12) Eppler, R.: Airfoil Design and Data, Springer-Verlag, Tokyo, 1990, pp. 378-379, 488-489. 